\title{
IMPLEMENTING GOOGLE CLASSROOM IN ENGLISH LEARNING AT STIT AL-ITTIHADIYAH LABUHANBATU UTARA
}

\author{
Gumarpi Rahis Pasaribu \\ gumarpi19@gmail.com \\ STIT Al-Ittihadiyah Labuhanbatu Utara
}

\begin{abstract}
The use of technology in the learning process is something that is always used. In the industrial era 4.0, the lecturer is required to have sufficient ability to keep up with technological developments. Learning that focuses on face-to-face processes must be integrated with blended learning. This condition makes Google as one of the largest web tools to introduce Google Classroom (GC) in 2014. The existence of GC is expected to be a solution to problems such as the lack of English lesson hours at the junior high school level. But unfortunately, there is still a lecturer who still does not know about the benefits of GC. So that through this service, it is hoped that it can provide a holistic picture related to the use of GC, especially in learning English. Further, this service is expected to improve student's English language skills which include listening, speaking, reading, and writing skills. The dedication method is carried out in four stages, namely: a) analysis stage, b) material preparation stage, c) implementation stage, and d) activity report preparation stage. The result of this service is that all participating lecturer is not familiar with GC, so the lecturer is very enthusiastic and interested in using GC. Lecturer knows the platforms that they can use in learning that is integrated with blended learning. The lecturer can more easily manage class assignments quickly and provide feedback to students effectively.
\end{abstract}

Keywords: Google classroom, blended learning, industrial technology 4.0

\section{INTRODUCTION}

Technological developments that occur so rapidly have changed almost the entire order of social life, ranging from economic activities with the use of electric money, the use of online-based transportation, to the use of technology in education with the introduction of online learning or also known as blended learning. In simple terms, blended learning is defined as combining learning in the classroom with e-learning. In Indonesia, the use of onlinebased learning is well known, as can be seen from the use of online-based learning platforms which are quite attractive to lecturer, such as the use of Edmodo, Schoology, and Google Classroom. 
Google as a web tool platform that is very interesting and has many functions, makes it easy for its users to get various kinds of information needed. In 2014, Google introduced a special platform that is used as a tool to assist the implementation of learning, namely Google Classroom. Google Classroom (GC) helps lecturer to create and organize classwork quickly and easily, provide direct feedback to students efficiently, and communicate with students without being limited by space and time. GC is considered as the best platform that can improve teacher performance. GC provides very useful facilities that students can take advantage of. GC helps lecturer to organize classes, utilize time and improve the quality of communication with students (Latif, 2016).

However, through several literature reviews, the use of GC has not been widely used. This is caused by various factors, including technical, tactical, economic, and social factors. In fact, the use of GC can help lecturer to overcome the limited number of hours of English lessons in schools. This is supported by Megahantara (2017) giving a positive impact in the learning process.

At this time students get English learning materials only focusing on developing linguistic knowledge such as grammar and understanding of reading texts, whereas in reality the ability to communicate which is reflected in the ability to speak, listen, read and write English is a capital which is an important point that must be developed. . This happens due to the limited number of hours of lessons and the large number of students who average $30-40$ people in one class, so that lecturer have difficulty in assess the English language ability of each student with a limit of the number of hours of lessons in 1 week as much as 4 hours of lessons.

Seeing the existing problems and the usefulness of GC, this service would like to introduce the use of GC in the English language learning process to junior high 
p-ISSN: 2085-1383; e-ISSN: 2621-4156

school lecturer and the equivalent in the Jalan Cagak sub-district, Subang district. The purpose of this service is the application of Google Classroom in the English learning process. It aims at the use of GC in English subjects, which more broadly is to develop students' English skills.

The year 2018 was a turning point for the introduction of industry 4.0, where all social, economic, political, and even educational aspects rely on the greatness of technology, especially internet use. This is supported by Holyes \& Lagrange (2010) that the most influential thing in the world of education is the use of technology. In the world of ICT education is not new, where the use of information media such as Schoology or Edmodo as learning media is included in the widely used English learning application.

In general, ICT in learning can be defined as the use of internet media in the learning process. In a simpler perspective, the use of computers, projectors, television, radio, and other electronic devices in the learning process is also considered a form of using ICT (Fu, 2013). In the development of the learning process, we know that there are pros and cons to the use of ICT. However, ICT in general can facilitate the learning process where lecturer can have a wider workspace. This is also supported by the opinion of Suryani (2010), where the use of ICT in the classroom has many advantages that can help the learning process. Using technology can make students more active. Students will also be more aware of what information they need,

Google as one of the largest web tool providers in the world introduced Google Apps for Education, abbreviated as GAFE. One of the applications that contained in GAFE is Google Classroom which was first introduced in 2014. This application is an application that can be easily accessed by all lecturer and students. GC can be used on both home computers, laptops, and even strings. For string users with 
Android and IOS operating systems, GC can be accessed easily on the Google Play Store and Apple Store.

$\mathrm{GC}$ is a free application, so GC is considered very suitable for use in developing countries, or specifically can be used by schools that have limited funds in developing the use of ICT in their learning process. GC can also be used as a tool to regulate the learning system at the school to college level. With GC lecturer can effectively and efficiently manage classrooms (Azhar \& Iqbal, 2018).

English language skills are grouped into two groups, namely receptive skills and productive skills (Lotherington, 2004). Receptive skills focus on developing students in obtaining information from spoken and written sources. Skills included in this group are listening and reading skills. While Productive skills focus on developing students in making a written work and being able to communicate well using a certain language. Skills included in this group are speaking and writing skills.

Likewise, between the ability to read and write, writing is considered as a result of good reading skills, and by having good reading skills students will have wider access to explore their writing skills. This is supported by a statement from Lorena \& Sadiku (2015), listening and speaking are integrated skills, and it will be effective to make effective communication, while, reading and writing are integrated too and make effective written communication. In other words, combining all these skills can be a very good solution to improve students' communication both in oral and written communication.

\section{RESEARCH METHOD}

The stages of this service include four stages, namely: a) the analysis stage, b) the material preparation stage, c) the implementation stage, and d) the activity report preparation stage. 
1. Stages of analysis

At this stage, we conducted interviews with the lecture of the English of STIT Al-Ittihadiyah Labuhanbatu Utara explained about the activities to be carried out. This activity was attended by lecturer of English subjects at STIT Al-Ittihadiyah Labuhanbatu Utara. Google Classroom was chosen to increase the use of technology in learning to facilitate classroom management to achieve effective learning objectives.

2. Stages of Material Preparation The implementation team made the preparation of materials based on the previous analysis stages. At this stage, the team compiled guidelines for using Google Classroom by using several references that were in accordance with the material. The following are definitions and guidelines for using Google Classroom for lecturer.

\section{Stages of implementation}

This activity was carried out on Saturday, August 11, 2021, in STIT Al-Ittihadiyah Labuhanbatu Utara. At this stage, the presenter explained what GC is and what benefits we will get as lecturer by creating GC accounts for our students. The next speaker explained how the steps in creating a google classroom account were. Lecturer are asked to take out their smartphones and access Google Classroom. The lecturer was very enthusiastic in creating a google classroom account and immediately put it into practice. In addition, lectyrer can create assignments, quizzes, or distribute assignments to students.

4. Stages of preparing activity reports

At this stage, the team reports on activities and the results of service activities that have been carried out. The results of the activities carried out are made for community service journals. 


\section{FINDINGS AND DISCUSSION}

Findings

After conducting training activities on google classroom for the lecturer of STIT Al-Ittihadiyah Labuhanbatu Utara, there were six findings, including:

First, the lecturer did not know anything about Google Classroom. So that lecturer have not taken advantage of the use of this technology in classroom management. The presenter explained in advance what google classroom is and what are the advantages when we use GC. Then, the presenter explains how to create a GC account. Here's how to get into GC is:

1. Open a browser then type google classroom. The speaker ensures that the lecturer already have a google account. After that a login page will appear and then the teacher enters his google account.

2. If it is successful, on the Google account page there will be an option, namely logging in as a lecturer and student. Choose as a teacher.
3. Then, on the home page $a+$ sign will appear, click to create a class. Fill in the name of the class, subject and classroom.

4. After that, the teacher can choose what information will be conveyed in class. There are announcements, assignments, questions.

5. The lecturer then distributes the class code to his students and students follow the steps at the beginning but join as students.

6. Students who have joined the class can be seen in the student list on the google classroom.

\section{Discussion}

After being guided by the presenters and the team to create a google classroom account. To make it easier for the lecturer to be made into five groups and the lecturer immediately created a google classroom account.

Second, the lecturer is very enthusiastic to make google classroom. This can be seen with all lecturers creating 
accounts and asking the presenters and the team when they face problems in making them. It is easier for lecturer to see and check the results of children's assignments without having to carry a lot of paper. Then, it is also easier for students to see the results of feedback given by lecturer anywhere, because GC can be accessed anywhere, not only at school but at home as well.

Third, from the results of interviews with lecturer, GC makes the data more centralized. So the teacher will no longer forget to save student data when students have done assignments, because all data is already stored in a google account. This can make learning more effective and efficient.

Fourth, lecturer can establish good communication and cooperation with their students. Because students can upload and ask what they don't understand, especially the material in the class. The teacher can also immediately explain when there are students who do not understand.
Fifth, the use of Google Classroom also supports the government's program on going green. This can be seen by reducing the use of paper used in collecting assignments, students type their assignments in MS Word and send them directly to the GC without having to print them. So, indirectly with the use of GC we help to protect the environment.

Sixth, one of the teacher participants had problems logging into his GC account because of his internet connection. This can be solved by using wifi from the presenter. However, this is a reference that a good internet connection is needed when we use GC. So, facilities in schools must also be supported by good internet facilities so that Google Classroom can be used by lecturer and students.

In general, the implementation of training activities for lecturer went well and smoothly. This proves that this training provides benefits to the lecturer and helps them to implement it in the 
classroom. It aims to improve the quality of learning in order to achieve learning objectives. This is in accordance with his theory that the use of technology has a positive impact on learning (Megahantara, 2017).

\section{CONCLUSION AND SUGGESTION}

(Based on the discussion, it can be concluded that the google classroom training for lecturer in junior high schools in Subang provides tremendous benefits for lecturer. Lecturers are very enthusiastic and interested in using google classroom, lecturer know the applications they can use in learning, lecturer can more easily manage classes, save time, and provide examples for students to protect the environment by reducing paper use.

However, facilities such as the availability of good connections must also be supported by each school. Because with good facilities it can make it easier to use a google classroom account. This is in line with the demands of education in the 4.0 era. Thus, a good synergy is needed not only for the creativity of the teacher but also for the facilities to be in line to achieve a better quality of learning.

\section{REFERENCES}

Azhar, KA, \& Iqbal, N. (2018). Effectiveness of Google Classroom: Lecturer' Perceptions EFFECTIVENESS OF GOOGLE CLASSROOM : LECTURER '.PRIZREN SOCIAL SCIENCE JOURNAL, 2(2), 1-16.

Fu, JS (2013). ICT in Education: A Critical Literature Review and Its Implications Jo Shan Fu. International Journal of Education and Development Using Information and Communication Technology (IJEDICT, 9(1), 112-125.

Holyes, C., \& Lagrange, J.-B. (2010). Mathematics Education and Technology-Rethinking the Terrain. (C. Holyes \& J.-B. Lagrange, Eds.) (17th ed.). London: Springer.

Husain, N. (2015). What is Language? English Language Language as Skill. Research Gate, (March), 1-11.

Latif, S. (2016). Learning Engagement in Virtual Environments. International Journal of Computer Application, 148(11), 7-13. Retrieved from https://www.ijcaonline.org/archives/ volume148/number11/257992016911289.

Lorena, C., \& Sadiku, M. (2015). The Importance of Four Skills Reading, Speaking, Writing, Listening in a Lesson Hour. European Journal of 
Language and Literature Studies April, 1(1), 29-31.

Lotherington, H. (2004). What Four Skills Redefining Language and Literacy.pdf. TESL Canada Journal.

Megahantara, GS (2017). The influence of technology on education in the 21 st century. Yogyakarta: Yogyakarta State University.

Suryani, A. (2010). ICT in Education: Its Benefits, Difficulties, and Organizational Development Issues. Jsh Journal of Social Humanities, 3(1), 106-123. 